\title{
Slavoj Žižek on Jacques Derrida, or On Derrida's Search for a Middle Ground Between Marx and Benjamin, and His Finding Žižek Instead
}

Colby Dickinson

Loyola University Chicago, cdickinson1@luc.edu

Follow this and additional works at: https://ecommons.luc.edu/theology_facpubs

Part of the Philosophy Commons, and the Religious Thought, Theology and Philosophy of Religion Commons

Author Manuscript

This is a pre-publication author manuscript of the final, published article.

\section{Recommended Citation}

Dickinson, Colby. Slavoj Žižek on Jacques Derrida, or On Derrida's Search for a Middle Ground Between Marx and Benjamin, and His Finding Žižek Instead. Philosophy Today, 59, 2: , 2015. Retrieved from Loyola eCommons, Theology: Faculty Publications and Other Works, http://dx.doi.org/10.5840/

philtoday201522665

This Article is brought to you for free and open access by the Faculty Publications and Other Works by Department at Loyola eCommons. It has been accepted for inclusion in Theology: Faculty Publications and Other Works by an authorized administrator of Loyola eCommons. For more information, please contact ecommons@luc.edu.

\section{(c) (i) $\odot$}

This work is licensed under a Creative Commons Attribution-Noncommercial-No Derivative Works 3.0 License. (C) 2015 Philosophy Today. 


\title{
Slavoj Žižek on Jacques Derrida, or On Derrida's Search for a Middle Ground Between Marx and Benjamin, and his finding Žižek instead
}

\begin{abstract}
:
Critiques of Derrida from contemporary Marxist positions are nothing new, though the nature and force of their argumentation need to be further analyzed in order to conceive of what stake Derrida will continue to have in our understanding of any political (Hegelian) inheritance within the coming decades. In this essay, I seek to advance the conversation between Derrida and his Hegelian-Marxist critics-with Slavoj Žižek's unique reading of Derrida being here foremost among them-in order to ascertain more precisely the framework of debate on dialectics and deconstruction that continues to define our realms of political representation.
\end{abstract}

Key Words:

Jacques Derrida, Slavoj Žižek, politics, hermeneutics, deconstruction 


\section{Slavoj Žižek on Jacques Derrida, or On Derrida's Search for a Middle Ground Between Marx and Benjamin, and his finding Žižek instead}

\section{Introduction}

In what has now become almost a caricature of itself, it was according to Jacques Derrida that the West's systematic rendering of historical dialectics functioned as a movement of mediation between two full presences. ${ }^{1}$ Derrida's subsequent negation of (the metaphysics of) presence, however, meant that he was also permanently stuck in-between two poles of thought, between, in words that Derrida himself utilized and which I have discussed elsewhere, canonical (representational) forms and their spectral messianic undoing. ${ }^{2}$ What Derrida pointed toward through such concepts, defined specifically in relation to Hegel, was the recognition of a form of dialectics practiced as a ceaseless interplay between general and restricted economies that yet comes to define our sense of identification (or "cultural intelligibility") tout court. The entire deconstructionist project, however, often seemed, to many, to hinge upon a decidedly one-sided view of this rather traditionally conceived—but perhaps also misunderstood-dialectics. This is a fact that, in the present instance, continues to draw our attention quite precisely to certain contemporary (Marxist) dialectical thinkers who opposed, and still oppose, Derrida's project, without, I will here suggest, fully comprehending the stakes in terms of what Derrida was actually attempting to perform as a more 'pure critique' of political structures and norms.

As Matthias Fritsch has already indicated, Derrida's conceptualization of dialectics in relation to messianicity is somewhat problematized when juxtaposed against his reading of Walter Benjamin, a figure for whom dialectics were not simply to be continued, but brought to a standstill. ${ }^{3}$ Such a reading of Derrida would, likewise, affect our understanding of Derrida's reading of Benjamin on issues concerning, for example, the role of violence within our world's

\footnotetext{
${ }^{1}$ See, among other places in his work, Jacques Derrida, Of Grammatology, trans. Gayatri Chakravorty Spivak (Baltimore: Johns Hopkins University Press, 1974), 296.

${ }^{2}$ See [to be completed after review].

${ }^{3}$ See the reading of Derrida offered in Matthias Fritsch, The Promise of Memory: History and Politics in Marx, Benjamin, and Derrida (Albany, NY: State University of New York Press, 2005).
} 
political representational frameworks (as in his essay 'Force of Law'). ${ }^{4}$ Recasting Derrida's reading of Benjamin as, indeed, somewhat problematic_-because he could not bring dialectics to a standstill as Benjamin had sought to, but only emphasized one end of their operations, the deconstructivist side - might allow us to reread Derrida with a new understanding of the political role of deconstruction.

Going even a step beyond this, as I intend to do in what follows, we might also be able to take such an interpretation of Derridean politics as indicative of a larger reading of dialectics as a whole. Indeed, Frederic Jameson's recent criticisms of Derrida, if read alongside Jameson's endorsement of Benjamin, might offer us an insight in this regard, as he presents a certain permanent 'suspension' of dialectics, claiming that there is, in truly following Hegel, no third term to be produced. Jameson, for his part, significantly aligns himself in this regard with Paul Ricoeur, a figure no less indebted to dialectical thinking, but often portrayed as more hermeneutical than his deconstructively-minded former colleague, Derrida. ${ }^{5}$

But, are Ricoeur and Derrida so different after all? That is, is deconstruction not capable of being perceived as a necessary partner in hermeneutical operations through and through? It is in light of such questions that I would ask: to what degree are Jameson's sustained critiques of Derrida yet in line with Derrida's own practice of dialectical methods? Are they as opposed as we often take them to be?

Critiques of "Derrida's politics" from contemporary Marxist positions are nothing new, though the nature and force of their argumentation need to be further analyzed in order to conceive of what stake Derrida will continue to have in our understanding of any political or Hegelian inheritance within the coming decades. In this essay, I seek to advance the conversation between Derrida and his Hegelian-Marxist critics—with Slavoj Žižek’s unique reading of Derrida being here foremost among them-in order to ascertain more precisely the framework of debate on dialectics and deconstruction that continues to define our realms of political representation.

\footnotetext{
${ }^{4}$ See Jacques Derrida, 'Force of Law: The "Mystical Foundation of Authority"' in Gil Anidjar, ed., Acts of Religion, trans. Mary Quaintance (London: Routledge, 2002). Cf. the essays on violence, politics and representation in Judith Butler, Frames of War: When Is Life Grievable? (London: Verso, 2009).

${ }^{5}$ See Frederic Jameson, Valences of the Dialectic (London: Verso, 2010).
} 


\section{Marxist critiques of Derrida's 'politics'}

It has been of interest to me as of late to witness a convergence of voices on the political Left concerning Derrida's 'failed' attempt to provide a substantial political theory of his own, one capable of putting forth an explicit and recognizable political agenda of some sort. My interest, in this sense, has centered primarily on the writings of Kenneth Surin, Frederic Jameson and, to a lesser extent, Antonio Negri. ${ }^{6}$ Such, more or less, traditionally Marxist writers have, seemingly, merged their critical aims in order to claim that "[t]he tragedy of the politics of subjectivity (at least the Derridean version thereof) is that it has no way of inserting the subject into the domain of the actually political". ${ }^{7}$ Despite what may be taken as the reluctance of some contemporary Derrideans to admit it, this comes across as a damning critique indeed, though one, perhaps, not wholly unexpected or unfamiliar: the failure to make a connection between deconstructivist methods and positive political projects-despite Derrida's own occasional forays into political issues-is a difficult one to achieve. As is well-known, even amongst the staunchest Derrideans, there have often arisen questions concerning the nature of the political within a deconstructivist framework, exactly what shape it might take, or how a deconstructivist reconfiguration of the political might actually constitute a challenge to the entire structure of politics in the first place. ${ }^{8}$

But is an aporetic position the only conclusion one can draw from all of Derrida's dealings with the political structures that be? Is there yet another potential way to view deconstructionism in light of our given political representations? And how might an attempt to illuminate the problematics inherent within the political itself assist us in re-describing the deconstructionist project?

In many ways, answering such questions has become a favorite pastime of Derridean scholars, one that allows them to reiterate the basic philosophical implications of Derrida's oeuvre alongside a standard critique of operations deemed 'normal' within the political sphere.

\footnotetext{
${ }^{6}$ Kenneth Surin, Freedom Not Yet: Liberation and the Next World Order (Durham: Duke University Press, 2009) and Jacques Derrida, Terry Eagleton, Frederic Jameson and Antonio Negri et al., Ghostly Demarcations: A Symposium on Jacques Derrida's Specters of Marx (London: Verso, 2008).

${ }^{7}$ Surin, Freedom Not Yet, 195.

${ }^{8}$ See, among others, the excellent overview of some of the challenges faced by Derrida's earliest and most loyal commentators when contemplating the political in Nancy Fraser, 'The French Derrideans: Politicizing Deconstruction or Deconstructing the Political?' in Gary B. Madison, ed., Working Through Derrida (Evanston, IL: Northwestern University Press, 1993), 51-76. See also, the more systematic overview given in Richard Beardsworth, Derrida and the Political (London: Routledge, 1996).
} 
The seemingly larger issue at stake in determining why Derrida was 'unable' to give a direct answer to his critics was one succinctly pointed out by Geoffrey Bennington, a longtime collaborator with Derrida, and one of his staunchest advocates.

In response to those demands that Derrida issue a political program of some kind, Bennington responds by suggesting that "[...] it is misguided to expect Derrida's work to answer to the concepts of 'politics' or 'political philosophy' just because these are metaphysical concepts - and insofar as Derrida's constant concern has been to comprehend and exceed metaphysics, he can hardly be expected to rely simply on metaphysical means to do so". 9 Reading Derrida's deconstructivist work as such allows us to see how his refusal to engage with a 'positive political project' is really a refusal to engage in the traditional metaphysical constructions that undergird the typical atmosphere of the political. Such a refusal, Bennington urges, should be enough to silence those Marxist critiques, such as, he notes, those offered by Frederic Jameson or Terry Eagleton. He continues by stating that

[...] if Derrida were ever simply to answer to that demand, to provide an answer which that demand could hear and accept, then his own thinking could safely be located in the metaphysical tradition he has always claimed to outflank. In this sense, Derrida providing a political answer to his political critics would prove just the opposite of what they would take it to prove, and so we might say that he stands a chance of proposing something radical about the political just to the extent that his texts do not answer simply to that demand. ${ }^{10}$

Rather, and rehearsing a number of themes prominent in the later Derrida's work, such as in The Politics of Friendship, Rogues or Specters of Marx, ${ }^{11}$ his insistence upon a spectral force of messianicity moving within our most normative social structures—subtly deconstructing them from within as a way to guarantee that such structures would always contain within themselves the ("autoimmune") ability to deconstruct themselves, to become potentially more "just" and thereby to increase their chances of being more "democratic" over time, though never fully embodying the "democracy still to come"-was certainly a direct political consequence of his

\footnotetext{
${ }^{9}$ Geoffrey Bennington, Interrupting Derrida (London: Routledge, 2000), 19. See also, what is in many ways the continuation of this theme in Martin McQuillan, ed., The Politics of Deconstruction: Jacques Derrida and the Other of Philosophy (London: Pluto Press, 2007).

${ }^{10}$ Bennington, Interrupting Derrida, 23-24.
} 
deconstructivist stance. ${ }^{12}$ It was one, moreover, that spoke to the entire realm of the political, its foundation, practice and its continued existence.

Such a vision of this "radical democracy", open to whatever may come ('them') to deconstruct our most basic political version of 'us' (e.g. the permanent 'other' within the 'self', etc.) - and which notably comes from within as much as from without-was hinged upon a form of open hospitality to the 'other' without name. Its 'form' was as much spectral as anything else-a continuous call for more democratic forms to emerge, but never to really find a historical, concrete embodiment of an ideal 'Democracy'. Though such a thing could never exist in reality, it does not mean that one should not keep trying to bring about such a state. In this vein, we might note Richard Rorty's early critique of Derrida's political program, which was that it consisted of an open invitation to a radical form of otherness and might instead actually be the very thing needed to invite new forms of (political and social) monstrosity into our lives. Rorty's critique, at least in some Derridean commentators' eyes, merely serves as an attempt to 'domesticate' Derrida by rendering the radicality of deconstruction's political implications into a tame specter, and, thus, removing its political force altogether. ${ }^{13}$ Despite Rorty's critique, however, this Derridean version of open hospitality has since been echoed, in many ways, by Richard Kearney's religious openness to a 'God Who May Be', which, likewise, has been criticized by theologians who question what (theological) 'monsters' might also be let in through such an open invitation. ${ }^{14}$

There is no doubt, of course, that the radical 'openness' of hospitality, with its accompanying implications for practical matters, such as immigration reform and the construction of national borders - all of which point toward, what Michael Naas has delineated

\footnotetext{
${ }^{12}$ Jacques Derrida, Specters of Marx: The State of the Debt, the Work of Mourning and the New International, trans. Peggy Kamuf (London: Routledge, 1994), The Politics of Friendship (trans. George Collins, London: Verso, 1997) and Rogues: Two Essays on Reason, trans. Pascale-Anne Brault and Michael Naas (Stanford: Stanford University Press, 2004). On the relationship between messianicity and democracy, see Michael Naas, Miracle and Machine: Jacques Derrida and the Two Sources of Religion, Science, and the Media (New York: Fordham University Press, 2012), 152-201. See also the 'political supplement' to deconstruction, taken up in the form of democracy, in Simon Critchley, The Ethics of Deconstruction: Derrida \& Levinas (Oxford: Blackwell, 1992), 188-241, and the essays gathered in Arthur Bradley and Paul Fletcher, eds., The Politics to Come: Power, Modernity and the Messianic (London: Continuum, 2010).

${ }^{13}$ See Fabbri, The Domestication of Derrida, 126.

${ }^{14}$ See Lorenzo Fabbri's commentary upon the relationship between Rorty and Derrida in his The Domestication of Derrida: Rorty, Pragmatism and Deconstruction (London: Continuum, 2008), 115-27. See also Richard Kearney, The God Who May Be: A Hermeneutics of Religion (Bloomington, IN: Indiana University Press, 2001), as well as Lieven Boeve, 'God, particularity and hermeneutics: A critical-constructive theological dialogue with Richard Kearney on continental philosophy's turn (in)to religion', Ephemerides Theologicae Lovanienses 81:4 (2005), 305333.
} 
as "a thorough-going critique of the proper, of claims to ownership, propriety, and purity"15does contain a viable and, at times, even practical, political posturing, one needing to be exercised much more than it has been within the pragmatic political sphere. From a certain viewpoint, Derrida's efforts point toward a permanent critique of politics that resonates with many on the Left, and which offers itself as a cautionary position to any political program, Right or Left.

What I would like to do here, however, is to open the conversation between Derrida and the political a bit further in an effort to engage his thought precisely as an example of the impasse that many people do encounter between the theoretical-philosophical and genuine political action. By taking a look at the intersection of violence, representation and dialectical thought in Derrida's work as a witness to the difficulty—and yet, perhaps, also necessity—of finding concrete (material) political responses to philosophical problems, I am hoping to sketch some tentative conclusions regarding the larger political hermeneutics within which Derrida's work is implicated, and, perhaps, to accomplish this despite the fact that many Derrideansfocused mainly on the deconstructive act itself-might sometimes miss out on this larger picture. ${ }^{16}$ It is in such a light that I want, ultimately, to consider what I will call another approach to Derrida's thought, one taken through the detour of another Marxist thinker whose work might actually point us toward another, more productive reading of Derridean politics: Slavoj Žižek.

\section{Blindness and insight, laughter and dialectics}

The reduction of an author to a caricature or generalization inevitably loses the complexity and nuance of the positions he or she maintains. It is also, however, seemingly the zero point for forming one's own authorial 'subjectivity' (self-representation, or autobiography). The implications of such a self-recognition are significant, as the conflict of interpretations often

\footnotetext{
${ }^{15}$ Michael Naas, Taking on the Tradition: Jacques Derrida and the Legacies of Deconstruction (Stanford: Stanford University Press, 2003), 166. See also, Michael Naas, Derrida From Now On (New York: Fordham University Press, 2008), 122-46.

${ }^{16}$ Such has been my interest, for example, in the work of Giorgio Agamben, who, though often at great odds with Derrida, at least directly attempts to provide such a bridge between the philosophical and the political. [Reference to be added after review.]
} 
rages most over the 'originality' of one's reading of a particular 'original' text (and, preferably, in its 'original' language). Whose reading seems, therefore, to best grasp the 'original' meaning (or intention) of the text? And, how does such a reading help develop one's own subjective perspective or authorial argument?

Derrida himself would not claim that he could access the 'original' meaning of a text, and he had no intention of doing so, as, in his eyes, such a claim would equally be a claim to sovereign power. Such an exclamation was what he felt put him at great odds with someone like Giorgio Agamben, for example, an author whom, he claimed, always sought to be the first to reach the originary ground and to declare the results of his find as an 'original' discovery of the meaning to be found there. ${ }^{17}$ Yet, I would ask, does Derrida's refusal to search for the 'origins' (in a Freudian sense) mean that he is, more or less, open to blatant misreadings of texts-a question which Agamben himself asked of Derrida from time to time? ${ }^{18}$ If so, how did this function in his work, and to what degree did it dominate the styles and methods with which he wrote?

Slavoj Žižek, in his Less Than Nothing, points out how Michel Foucault, one of the three great archaeologists that Derrida critiques (Freud and Agamben being the other two) seemed to acknowledge Derrida's reproach of his attempt to locate the 'origin' of madness and to let madness speak for itself, devoid of the authorial-subject's involvement in its expression. ${ }^{19}$ The author is always involved in the expression of a text, as there is nothing but this text in which the author asserts his or herself. The articulation of an object will always be mediated by the subject who sees it and attempts to express something of its nature. Derrida's position, therefore, is one of being always-already in-between texts and expressions, in-between an unlocatable 'origin' and its final (ultimately unrealizable) 'realization', and not at an extreme point of claiming to have all the answers from a fixed, or polarized, position. Putting things as such raises an essential question to my mind: is such a position not too hermeneutical for deconstructionism? Or, perhaps, such a position might be just too hermeneutical for subsequent Derrideans?

\footnotetext{
${ }^{17}$ See, among others, Jacques Derrida, The Beast and the Sovereign, vol. 1, ed. Michel Lisse, Marie-Louise Mallet and Ginette Michaud, trans. Geoffrey Bennington (Chicago: University of Chicago Press, 2009), 92-93 and 316317.

${ }^{18}$ See, among others, Giorgio Agamben, 'The Friend', What Is an Apparatus? and Other Essays (trans. David Kishik and Stefan Pedatella, Stanford: Stanford University Press, 2009). See also Derrida's related critique of Freud in his Archive Fever: A Freudian Impression, trans. Eric Prenowitz (Chicago: University of Chicago Press, 1996). ${ }^{19}$ Slavoj Žižek, Less Than Nothing: Hegel and the Shadow of Dialectical Materialism (London: Verso, 2012$), 332$.
} 
The reality of such a subjectivity is more 'plastic' (in the sense of Catherine Malabou's use of "plasticity", a term taken up from Hegel) than many would read Derrida as liking to admit—for to be engaged in plasticity is to be suspended in-between the poles of thought, precisely to be hermeneutical through and through. ${ }^{20}$ I wish, in many ways, to focus on this notion of a hermeneutical Derrida, though not a hermeneutical form of deconstructionism itself - that is, I want to look at their compatibility but not their being rendered synonymous, as I believe that such a reading of Derrida might bring us closer to comprehending the politics of Žižek, whatever such a thing may be in the end.

Žižek, for his part, continues his infrequent references to Derrida in Less Than Nothing with a comment upon Paul de Man's reading of Derrida's deconstruction of Rousseau in Of Grammatology, observing, most notably, that Derrida neglects those auto-deconstructive motifs already "operative" in Rousseau's own work - a most intriguing suggestion to make concerning the philosopher who sought above all else to identify a text's "autoimmune" deconstructive impulses. The suggestion here, of course, is that Derrida neglects Rousseau's self-reflexive acts so that he himself might provide them - that he, in some sense, might rather appear to be the one who has 'mastered' Rousseau's own text — the very charges that Derrida had once levied against Agamben, and that Agamben has also levied at Derrida from time to time. What de Man, and Žižek following him, sees in this is more than simply an oversight on Derrida's part; it is rather the very structure of his deconstructivist methods, the means of the establishment of his authorial subjectivity, and, hence, his need to distance himself from those whom he perceives as performing a similar gesture (i.e., most directly in his lectures on The Beast and the Sovereign with regard to Agamben). As Žižek himself puts it: "[...] this oversight is not an accident, but a structural necessity: Derrida can only see what he sees (deploy his deconstructive reading) through such blindness. And it would be easy to demonstrate the same paradoxical overlapping of blindness and insight in other great Derridean readings_-say, for his detailed reading of Hegel in Glas". 21 Though there may be a way to read Derrida's 'blindness' as constitutive of his distance from the political, it is also what motivates his incessant critique of politics.

Derrida's reading of Hegel in particular interests Žižek because it is a form of Hegelian dialectics (or at least his definition of those dialectics)—one that stands in opposition to

\footnotetext{
${ }^{20}$ See Catherine Malabou, The Future of Hegel: Plasticity, Temporality and Dialectic, trans. Lisabeth During (London: Routledge, 2005).

21 Žižek, Less Than Nothing, 279.
} 
Derrida's stated (fundamental) position —-that Žižek, for his part, seeks not solely to dismantle, as with other Marxist critics, but to recover as well. ${ }^{22}$ According to Žižek's reading of the matter, Derrida reduces Hegel's complexity to a simplistic 'metaphysics of presence', and such judgment is what allows Derrida to attempt, for example, to counter the entrance into dialectics with laughter, or that which exceeds the dialectical system. ${ }^{23}$ We can recall on this count Bennington's earlier defense of Derrida as one who escapes the metaphysical underpinnings of the political, though what we still have to square ourselves with are the very maneuversannoying to so many writers, yet admired and imitated, even stylistically, by his most devout followers- that Derrida makes in order to achieve this exalted position from which to critique all that comes before him.

Perhaps this is the very spot where so many of those critical of Derrida's methods converge, and for good reason. Take, for example, William Desmond's essential critique of Derrida, that he " $[\ldots]$ is a kind of dialectical thinker who tries to use dialectic to confound dialectic. The results are, however, equivocal, as we see this hermeneutical vacillation between [a Levinasian] generosity and [a Nietzschean] suspicion". ${ }^{24}$ Derrida's impulses thus 'make hay' with the metaphysical undecidability inherent to the antinomies of thought, according to Desmond, an activity which Derrida's somewhat hesitant Kantianism seemed to grasp. ${ }^{25}$ As Desmond perceived the situation: "Deconstructivist skepticism seems to me to be closer to Kant than to Hegel". ${ }^{26}$ Simon Critchley and Kevin Hart, to name only two more prominent voices, have also echoed this portrayal of Kantian influence in Derrida's work. ${ }^{27}$ And, herein lies, perhaps, the seeds for the significant conflict Derrida maintained with Hegel throughout his career, that which, Žižek reminds us, failed to actually take in the necessary dialectic between blindness and insight which remains within any author's given work.

\footnotetext{
${ }^{22}$ See also Žižek's critique of Derrida's messianic ethics- 'deconstruction as justice' — which can be said to rest upon 'a utopian hope which sustains the specter of "infinite justice," forever postponed, always to come, but nonetheless here as the ultimate horizon of our activity', and which Žižek finds needs to be relinquished in order to rid oneself of the 'Big Other' that lingers within such speculative constructions. See Slavoj Žižek, In Defense of Lost Causes (London: Verso, 2008), 225.

${ }^{23}$ William Desmond, Beyond Hegel and Dialectic: Speculation, Cult, and Comedy (Albany: State University of New York Press, 1992), 263.

${ }^{24}$ Desmond, Beyond Hegel and Dialectic, 268-9.

${ }^{25}$ Desmond, Beyond Hegel and Dialectic, 276.

${ }^{26}$ Desmond, Beyond Hegel and Dialectic, 289.

${ }^{27}$ See the collection of essays gathered in Phil Rothfield, ed., Kant After Derrida (Manchester: Clinamen Press, 2002).
} 
Derrida's insistence seemed to be projected upon the use — but only partial disclosure of—his methods. Žižek's critique would seem, then, to be a merciless unveiling of the 'real' dynamic operative within Derrida's reading of particular texts (something which, again, repeats Agamben's similar critique in many ways). What I want to point to beyond these accusations, and alleged authorial, stylistic tactics, is the manner in which these philosophical-theoretical maneuvers continue to perpetuate themselves as something inherent to the very nature of critique itself - that which is necessary for forming any political critique at all, but which is often mistaken as having nothing to do with politics. ${ }^{28}$

Despite such criticism of the Derridean project, or, likewise, any response from the Derrideans eager to revisit the metaphysical foundations of politics, Desmond is right, I would wager, to point toward this Kantian legacy and a potential hermeneutic at work in Derrida—one taken up far less prominently than his deconstructivist position, which would otherwise indicate a radically one-sided project (something which his work has been mistaken for advocating almost from the beginning). ${ }^{29}$ Failing to note the significance of this larger hermeneutical backdrop to Derrida's work has been, perhaps, the difficulty many have sensed latent in Derrida's theoretical writings from the start: the deconstructive act is timely, profound and much needed, but what of his positive political project? And, I would here add, what of any hermeneutics beyond deconstruction, of any practical medium between a concept's being taken apart and its being reconstituted in some sense?

As we well know from the work of Paul Ricoeur, for example, hermeneutics must point both backward and forward, both toward the arche and toward the telos-it engages the construction of meaning as a process of totalization, de-totalization and re-totalization. ${ }^{30}$ It must find an interpretation of the state of things in the place where it stands in-between such poles of orientation, and within the constant recreation of our symbolic totalities. Maybe, I am suggesting, Derrida's attempt to deal with a future yet always 'to come' later in his career was just such an effort to balance deconstruction with its forward-looking partner (a spectral

\footnotetext{
${ }^{28}$ Žižek's frequent insistence upon 'doing nothing' or simply 'thinking' in the face of political pressures would seem like an apt illustration of such an open-ended, but productive, critique of political power.

${ }^{29}$ See the many (mis)descriptions noted in Cusset, François, French Theory: How Foucault, Derrida, Deleuze, \& Co. Transformed the Intellectual Life of the United States, trans. Jeff Fort (Minneapolis: University of Minnesota Press, 2008), 107-28.

${ }^{30}$ See, for example, Paul Ricoeur, The Conflict of Interpretations, ed. Don Ihde (Evanston: Northwestern University Press, 1974), as well as his Time and Narrative, 3 vols., trans. Kathleen McLaughlin and David Pellauer (Chicago: University of Chicago Press, 1985).
} 
'messianicity' of which he spoke often). ${ }^{31}$ It was this very tension, for example, that actually pushed Derrida to declare that any deconstructive, messianic force must be put up against a canonical measure, one that would be challenged, yes, but which would also have to be defended, in some sense, as necessary to any communicable sense of intelligibility. ${ }^{32}$

I think that such a reading of Derrida is plausible on a number of levels, and this reading might also provide an answer to the pressing questions that Žižek had initially asked: how are we to read the dialectic of blindness and insight in Derrida's work? Should we simply register such dynamics and misreadings as no more than the inherent "impossibility of our ever reaching the standpoint of infinity, of an insight no longer marred by any kind of blindness"? ${ }^{33}$

Contrary to what one might expect at this juncture-a sustained critique of Derrida's blindness, as others have attempted to do on numerous occasions-Žižek points toward what, I think, constitutes his uniqueness in responding to Derrida with what he terms the Hegelian answer: the only way to correctly perceive the object of our gaze is through an intentional 'narrowing' of our focus, through a partial 'blindness' which allows us to see what lies before us and which renders the margins of our sight either blurry, inconsequential or omitted from view. This somewhat partial defense of Derrida's deconstructivist methods is what Suzanne Gearhart has elsewhere referred to as the necessary repression involved in cultural (familial) inscription, something that comes particularly to light in Derrida's reading of Hegel (as both Žižek and Gearhart contend). ${ }^{34}$ Žižek's example here, to help us understand such a purposeful narrowing process, involves the tactic of grasping the fundamental point of a book precisely by not reading the entire book, and, therefore, not getting lost in the minutiae of its argumentation-a statement that perhaps brings new life to Derrida's claim that he himself did not read great quantities of writing, but what he did read, he read very closely, and well. ${ }^{35}$ This maneuver is, perhaps, also what presents the readers of both Derrida and Žižek with a certain stylistic overlap, as both writers continuously maintain a penchant for meandering digressions, what appear to be partial

\footnotetext{
${ }^{31}$ See, for example, Derrida, Specters of Marx.

${ }^{32}$ See the revealing interview Derrida gave to Richard Rand, where he spoke in defense of canonical structures of representation, titled 'Canons and Metonymies' in Richard Rand, ed., Logomachia: The Conflict of the Faculties Today (Lincoln: University of Nebraska Press, 1992).

${ }^{33}$ Žižek, Less Than Nothing, 279.

${ }^{34}$ Suzanne Gearhart, 'The Remnants of Philosophy: Psychoanalysis After Glas' in Stuart Barnett, ed., Hegel After Derrida (London: Routledge, 1998), 159.

${ }^{35}$ See the documentary where he mentions such reading habits, Amy Ziering and Kirby Dick, Directors, Derrida, 2004.
} 
readings of texts, all presented while simultaneously maintaining a remarkable consistency in their work, as Adrian Johnston has elsewhere observed. ${ }^{36}$

From a hermeneutical perspective, these expressions are reminiscent, I would add, of Ricoeur's efforts to define a "happy memory" that must, by necessity, forget certain things in order to construct its point of view. This memory, in order to be "happy", and, therefore, also in some sense "just", must be capable of remembering things it has forgotten (or of "turning its head" to "see" other things just beyond the narrowed gaze), not then guilty of a violent repression or of ignoring things which at times need to be recalled (seen or even heard). ${ }^{37}$ There may be a necessary forgetting enacted, thereby, in order to narrow one's focus, and in order to establish and maintain a sense of subjectivity at all — the point each of these thinkers seems to be rehearsing in a number of ways throughout their oeuvres. In this fashion, we witness, as well, Gearhart's reading of Derrida's interpretation of Hegel as a form of dialectics that hinges upon an understanding of undecidability as a sort of permanent tension between repression and Aufhebung. ${ }^{38}$ Indeed, for her, the logic of dialectics is the logic of undecidability, thus bringing Derrida closer to a certain reading of Hegel than others might have measured it to be. ${ }^{39}$

What Žižek adds to this discussion, and it is a point well worth considering in full, stands in contrast with the standard Marxist critiques of Derrida's (non)political theorizing. For Marxist political theorists, such as Jameson, Surin and Negri, Derrida's endless textual play fails to approach a concrete materialist political program. Marxists would rather side with someone like Foucault, for whom such historical discursive practices are the very essence of philosophical reflection, as Žižek himself notes. ${ }^{40}$

It is more interesting to me then, albeit perhaps somewhat problematic, to read Žižek's comments on Derrida as a possible attempt to find the hermeneutical core of Derrida's thoughtand this despite Derrida's frequent emphasis on the deconstructionist side only-a slightly ironic claim made in light of Jameson's recent simultaneous critique of Derrida alongside his own laudation of Ricoeur's hermeneutics. ${ }^{41}$ For Jameson, Derrida's insights fail for the same reasons

\footnotetext{
${ }^{36}$ Adrian Johnston, Žižek’s Ontology: A Transcendental Materialist Theory of Subjectivity (Evanston: Northwestern University Press, 2008), xvi-xvii.

${ }^{37}$ Paul Ricoeur, Memory, History, Forgetting, trans. Kathleen Blamey and David Pellauer (Chicago: University of Chicago Press, 2004), 494ff.

${ }^{38}$ Gearhart, 'The Remnants of Philosophy', 159.

${ }^{39}$ Gearhart, 'The Remnants of Philosophy', 173.

40 Žižek, Less Than Nothing, 333.

${ }^{41}$ Jameson, Valences of the Dialectic.
} 
that Surin indicates: his deconstructionist tendencies fail to embody a concrete political praxis. Yet, Jameson embraces Ricoeur's hermeneutical vision as "so precious a resource" to the Left, despite his not normally being an "ally" to it, and this, despite the often problematic relationship between Ricoeur's own work and any sort of practical political agenda. ${ }^{42}$ Yet, if my reading of Derrida on this point—as illustrated by Žižek's incorporation of Derrida's 'true' methods—tells us anything, it is that Derrida is far more hermeneutical than the standard Marxist critique of his work would have us believe, bringing him far closer to someone like Ricoeur than many might anticipate. It also clues us in to another possible reading of Derrida's philosophical-political program, one that Jameson might be more welcoming toward.

Despite Jameson's dismissive claims regarding Derrida, amongst similar ones, is it yet possible to re-read Derrida through Žižek's interpretation of Derrida as a hermeneutical tactician - a move that, perhaps, places Derrida's take on politics much closer to Žižek's own position than many might have wagered to suppose $?^{43}$ Is it possible to recover a Derridean messianicity alongside his formulations on justice as part of a hermeneutical vision that also includes the defense of certain representational structures (though he shied away at times when asked about specifics) — and perhaps somewhat akin to Ricoeur's own methods—in order to provide a political hermeneutic that achieves much more than simply a deconstructivist stance?

\section{Conclusion}

[...] the time has come to draw the balance of my relations with Derrida, in a belated gesture of solidarity. Having written many pages in which I struggle with Derrida's work, now-when the Derridean fashion is fading away - it is perhaps the moment to honor his memory by pointing out the proximity of the topic of my work to what Derrida

\footnotetext{
${ }^{42}$ Jameson, Valences of the Dialectic, 485. See also the essays collected in Todd S. Mei and David Lewin, eds., From Ricoeur to Action: The Socio-Political Significance of Ricoeur's Thinking (London: Continuum, 2012), as well as, Greg S. Johnson and Dan R. Stiver, eds., Paul Ricoeur and the Task of Political Philosophy (Lanham, MD: Lexington, 2013).

${ }^{43}$ This resonance between Derrida and Žižek on the topic of the political has been noted, as well, by Aijaz Ahmad, who considers how ' $[\ldots$...] the kind of politics Zizek [sic] proposes, after his Leninist bluster, is remarkably similar to Derrida's' ( 50). Aijaz Ahmad, 'Three "Returns" to Marx: Derrida, Zizek, Badiou', Social Scientist 40: 7/8 (2012), 43-59. Such a closeness in terms of their respective theoretical-political structures is also suggested by Geoffrey Galt Harpham, 'Doing the Impossible: Slavoj Žižek and the End of Knowledge', Critical Inquiry 29:3 (2003), 453485, see especially 462 .
} 
called différance, this neologism whose very notoriety obfuscates its unheard-of materialist potential. ${ }^{44}$

In a somewhat long overdue homage to Derrida's early conceptualization of différance written shortly after Derrida's death, Žižek here makes clear his indebtedness to Derrida's work, linking his own key concepts together-everything from the "parallax gap", as a "pure difference that cannot be grounded in positive substantial properties", universality", which he often relates to his reading of a Christian universalism-with the fundamental concepts of deconstructionism. Though he refrains from an in-depth reading of Derrida's work, or any close textual scrutiny, Žižek does make clear the fact that Derrida's philosophical project, at least in its early emphasis on différance, is very close to his own efforts, though he has been, admittedly, reluctant to demonstrate this connection from time to timeperhaps, one might wager, due to the many Marxist critiques of Derrida that have been offered throughout the recent past. That such an alliance resonates deeply with both of their political formulations, however, should be, at this point, nothing of a surprise.

Derrida's reluctance to directly name those canonical structures he adhered to, and any accompanying political structures, taken together alongside his indirect adherence to a specific western canon through his choice of authors and topics to critique, obscured the point of his pure political critique-the significant parallel between Derrida and Žižek that I have sought to highlight in this essay. It is my contention that just such a Žižekian understanding of Derridean political thought - that he was in reality both an implicated hermeneut as well as master deconstructivist-is what, I believe, will primarily motivate the future receptions of both Derrida and Žižek, as well as their ultimate legacies as political philosophers of the highest caliber, though ones more cunning and indirect than some might like to portray them.

Despite Derrida's alternate distancing of himself from and yet indirect embrace of figures like Kant and Hegel, this is where his thought must be situated: between the "as if" and the "as such ${ }^{46}$, or between the general and restricted economies ${ }^{47}$, or the economic and aneconomic

\footnotetext{
${ }^{44}$ Slavoj Žižek, 'A Plea for a Return to Différance (with a Minor Pro Domo Sua)', Critical Inquiry 32:2 (2006), 226-249, 231. This essay was also reprinted under the same title in Costas Douzinas, ed., Adieu Derrida (London: Palgrave Macmillan, 2007), 109-133.

45 Žižek, 'A Plea for a Return to Différance', 244.

${ }^{46} \mathrm{I}$ have pursued this tension elsewhere in [reference to be added after review].
} 
processes that characterize Derridean thought ${ }^{48}$, or between canonicity and messianicity, as I have elsewhere framed it. ${ }^{49}$ Such is where I would, in the end, also locate Žižek, whose work continuously demonstrates just such a precarious positioning of views despite his obviously provocative suggestions made from time to time. These parallel gestures help us to see a Derrida who focused on the nature of the aporias in our midst, ones that are neither an antinomy nor part of any dialectics ${ }^{50}$, but, one might yet conclude, those which, nonetheless, found our antinomies and our dialectics alike, those structures of thought, social recognition and the political that continue to animate our world, and which it is both impossible and undesirable to do away with. They also assist us in comprehending something of what Žižek is, perhaps, really up to in his own work. How we bring both Derrida and Žižek into the political thought of this new century - and, likewise, develop a 'pure critique' of political structures — in many ways depends upon our ability to recognize the radicality of both authors, but also our ability to bring them together after all.

\footnotetext{
${ }^{47}$ See his early Hegelian essay 'From Restricted to General Economy: A Hegelianism Without Reserve', Writing and Difference, trans. Alan Bass (London: Routledge, 1978)

${ }^{48}$ See, among others who point out these same tensions, Andrea Hurst, Derrida Vis-à-vis Lacan: Interweaving Deconstruction and Psychoanalysis (New York: Fordham University Press, 2008).

${ }^{49}$ See [reference to be completed after review].

${ }^{50}$ Jacques Derrida, Aporias, trans. Thomas Dutoit (Stanford: Stanford University Press, 1993), 16.
} 